https://doi.org/10.48009/1_iis_2005_204-210

\title{
LIFELONG AND ON-LINE LEARNING IN HIGHER EDUCATION: A CASE OF SLOVENIA
}

\author{
Nada Trunk Širca, University of Primorska, nada.trunk@fm-kp.si \\ Lesjak Dušan, University of Primorska, dusan.lesjak@fm-kp.si \\ Žiga Čepar, University of Primorska, ziga.cepar@fm-kp.si \\ Viktorija Sulčič, University of Primorska, viktorija.sulcic@fm-kp.si
}

\begin{abstract}
In the past decade, there has been a tremendous growth in the field of lifelong learning. One of the newest and most promising methodological approaches in higher education is e-learning which is a relatively new computer technology and is significantly affecting the quality of lifelong learning. This paper investigates by first some theoretical concepts of life-long learning and legal factors affecting it. Second, it presents the results from a special survey focused on the group of postgraduate students of the Faculty of Management evaluating the relation of the participants in education to the introduction of different types of lifelong learning in the system of formal higher education and their equipment and qualification for using information and communication technology in the process of e-learning. The key finding is that the interest for implementation of e-learning is very high, especially in the case of non formal education and postgraduate education. The level of equipment and qualification for using information and communication technology is very high. Only a minority - about one percent of the questioned students - don't have an access to the internet. They mostly recognize knowledge and skills gained through work experience as part of a chosen higher education study program; they seem less likely to support knowledge acquired non-formally as part of a chosen higher education study program. They explicitly support the introduction of »education piece by piece « and its recognition as part of a chosen higher education study program. In the future we can expect an even faster development of life long learning and e-learning in Slovenia due to an adapted legislation.
\end{abstract}

Keywords: E-learning, lifelong learning, online course, higher education, distance learning, Slovenia.

\section{INTRODUCTION}

The concept of lifelong learning was first introduced in the seventies of the last century and has, until now, gone through different development phases offering many different views on education.

Lifelong learning was first used to give a clearer view on learning and education and their development, later it meant a link between formal and non-formal education, and between the young and adult education, described an education related to vocational activities, qualifying teachers or stressed the social model "a learning society" that rests on a responsible behavior of individuals and their values. In the 1980s the concept was not used due to recession and restricted public consumption, in the 1990s it was introduced again to solve the problem of unemployment. 
In the 1990s the focus shifted from lifelong education to lifelong learning. The latter includes an important element, i.e., the individual's responsibility for his own intellectual development.

The OECD (Organization for Economic Co-operation and Development), gives the following most commonly used definition of the concept: "This view on learning includes individual and social development of all dimensions - formal: in schools, organizations for vocational education, institutions of tertiary education and adult education, and informal: at home, at work and in the community. It is an open system that stresses knowledge standards and skills needed by all, regardless of age. It stresses the need for preparation and motivation for teaching children in their early youth and through the whole life. Efforts are oriented toward assuring the possibility of prequalification or broadening knowledge to all that need it - adults, employed, and unemployed" [4].

Such a definition allows the concept to include also programs of occasional learning and is thus one of the basic principles of the policy of the European Union. It first appeared in 1973 in the "Janne Report," and then in 1991 in the Memorandum of Higher Education in the European Community, and in the Memorandum of the Open Distance Learning in the European Community [4].

It is important that the programs of lifelong learning in higher education are tailored to meet the actual needs of potential participants that will, with a new and proper knowledge, answer to the needs of the economy. The limits and opportunities are set by the existent legislation, especially the Higher Education Act which recognizes the first professional and the university degree level without the formal education through the system of ECTS (European Credit Transfer System) which represents a big challenge and opportunity for higher education institutions [10].

The development of lifelong learning is also subject to current demographic trends. The main factors are the ageing of the academic work force [1], which effects the efficiency of the learning in higher education, the growing life expectancy at birth, low natality (and the change of the age structure of the population) and the growth of net migrations.

Lifelong learning has been submitted to challenges especially in the field of higher education. One of these challenges is represented by electronic learning or, in the jargon of the specialists, e-learning.

\section{REVIEW OF PREVIOUS RESEARCH}

According to one of the definitions, e-learning is one of relatively new forms of education supported by computer technology that is gaining importance in the face of improving the quality of learning and education. It combines sounds, photographs, pictures, two- and threedimensional animations, films, graphics and music with a number of user interaction elements such as pressing the buttons, clicking, using the keyboard. The information is accessible via the internet. E-learning is in this sense upgrading the multimedia technology that was one of the most important sources of inquiry on information machine equipment [2]. 
The main element of e-learning that distinguishes it from other multimedia tools in the field of lifelong learning is, above all, the interaction which turns passive listeners into actively engaged participants in the learning process. The Chinese philosopher Lao-Tzu described the meaning of interaction already in $30 \mathrm{BCE}$ when he stated the following: "If you tell me I will hear. If you show me I will see. If you let me experience it I will learn." Besides interaction, e-learning contains other elements. These are material or technological, human and virtual elements [2].

E-learning can be used in different processes of higher education: during the learning process, the teaching process, and during activities connected with the administration of both processes [6].

Participants are satisfied with e-learning mainly because it is an attractive, easy to use and entertaining system which provides an easy access to the information and communication technology and contains an active human element of e-learning, that is, the tutor [7].

The basic advantages of e-learning in the education system are better accessibility from almost every location in the world, lower education costs, easier access to literature and other learning material that is available on-line, the possibility to study at one's own pace and not in class, no time limits or transportation costs, and the programs are tailored to individuals.

Besides the advantages, there are also some drawbacks of e-learning. Some of the key ones include lack of face-to face interaction with a learning peer group preventing exchange of ideas, the access to bad or harmful information is not controlled, there is a need for a strong and qualitative supporting system for e-learning, there is the possibility of abuse of authorship of the on-line material [8].

Table 1. Typography of Different Possibilities of Using E-Learning [9]

\begin{tabular}{lll} 
Web-based training & Supported on-line learning & Informal e-learning \\
\hline Content-focused & Learner focused & Group-focused \\
Delivery-driven & Activity-driven & Practice-driven \\
Individual learning & Small-group learning & Organizational learning \\
Minimal interaction with & Significant interaction with & Participants act as learners and \\
tutor & tutor & tutors \\
No collaboration with other & Considerable interaction with & Multi-way interactions among \\
learners & other learners & participants
\end{tabular}

\section{RESEARCH QUESTIONS}

The existent Slovenian legislation enables the use of forms of non-formal first professional and university degree level education that have not been exploited until now.

The empirical research analyzes the relation of the participants in education to the introduction of different types of lifelong learning in the system of formal higher education and their equipment and qualification for using information and communication technology in the process of elearning. 
Specifically, we have been interested in providing answers to the following questions:

1) How is the Slovenian educational market prepared to introduce different forms and ways of lifelong learning in the higher education system and what is its point of view on this matter?

2) Are potential participants in higher education programs equipped and qualified for using information and communication technology?

3) What are the advantages of introducing forms of lifelong learning and e-learning in higher education and in what areas it would be most useful to introduce e-learning?

\section{THE METHODOLOGY AND THE DATA}

The data were collected by means of a questionnaire that was divided into two groups of questions: the first referred to the opinion and relation of postgraduate students to the introduction of different forms of lifelong learning in higher education, to the setting of motives and criteria for their introduction in higher education and on the organization's point of view on their introduction. The second group of questions exploited if students are prepared, equipped and qualified to use information and communication technology and what are the reasons for the introduction of e-learning in higher education.

The questionnaire was completed by a sample of 153 postgraduate students of the Faculty of management Koper, Slovenia. The research was carried out in January and February 2005.

The simple statistical analysis includes frequency distributions of answers on each question as well as some basic descriptive parameters such as mean value and standard deviation of the answers.

\section{EXPLORATORY ANALYSIS}

Let us have a look at some most important results based on the answers that have been collected.

1. According to all the answers analyzed, knowledge and skills gained through work experience should be recognized and should, on average, represent $31.6 \%$ of the study program. Table 2 shows that slightly more than half of the survey respondents indicated that the percentage should be lower or equal to the average.

Table 2. What Percentage of the Study Program Should be Represented by Knowledge and Skills Gained Through Work Experience

\begin{tabular}{ccccccccc} 
Answer & $\mathbf{0 \%}-$ & $\mathbf{1 0 \%}-$ & $\mathbf{2 0 \%}-$ & $\mathbf{3 0 \%}-$ & $\mathbf{4 0 \%}-$ & $\begin{array}{c}\mathbf{5 0 \%} \\
\text { and more }\end{array}$ & $\begin{array}{c}\text { No } \\
\text { answer }\end{array}$ & Total \\
\hline \% of answers & 14,6 & 17,5 & 27,2 & 11,7 & 14,6 & 7,8 & 6,6 & 100,0
\end{tabular}

$\mathrm{M}=31,6 \% ; \mathrm{SD}=16,2 \%$

2. More than half of the postgraduate students interviewed (55.3\%) think that the knowledge acquired non-formally should represent $20 \%$ of the study program. Almost $14 \%$ of the 
students did not answer this question, while on average this kind of knowledge should represent $23.5 \%$ of the study program.

Table 3. What Percentage of the Study Program Should be Represented by Knowledge Acquired Non-Formally

$\begin{array}{ccccccccc}\text { Answer } & \mathbf{0 \%}- & \mathbf{1 0 \%}- & \mathbf{2 0 \%}- & \mathbf{3 0 \%}- & \mathbf{4 0 \%}- & \mathbf{5 0 \%} \text { and } & \text { No answer } & \text { Total } \\ & \mathbf{1 0 \%} & \mathbf{2 0 \%} & \mathbf{3 0 \%} & \mathbf{4 0 \%} & \mathbf{5 0 \%} & \text { more } & 13,6 & 100,0\end{array}$

$\mathrm{M}=23,5 \% ; \mathrm{SD}=19,4 \%$

3. $75 \%$ of the respondents support the "education by course units." The answers were rated on a scale from 1 to 5 (1-least prepared, 5-most prepared). The average answer was 3.4. Students would choose this kind of education mainly because they could restore a balance between study commitments, work and family.

Table 4. Would You Choose the "Education by Course Units"? and Are You Prepared to Study by "Course Units"?

\begin{tabular}{ccccccccc} 
Answer & 1-least prepared & $\mathbf{2}$ & $\mathbf{3}$ & $\mathbf{4}$ & 5-most prepared & No answer & Total \\
\hline \% of answers & 8,7 & 15,5 & 24,3 & 21,4 & 25,2 & 4,9 & 100,0
\end{tabular}
$\mathrm{M}=3,4 \% ; \mathrm{SD}=1,3 \%$

4. Almost all of the respondents access the internet from home. $99 \%$ use the internet at home or at work. $1.9 \%$ of the students even have a wireless connection available.

Table 5. If and How Do Students Access the Internet

\begin{tabular}{cccccc} 
Answer & No access & $\begin{array}{c}\text { Only at } \\
\text { work }\end{array}$ & $\begin{array}{c}\text { At home through a wired } \\
\text { connection }\end{array}$ & Wireless connection & Total \\
\hline$\%$ of answers & 1,0 & 16,5 & 80,6 & 1,9 & 100,0
\end{tabular}

5. All of the respondents think they know how to use a computer; $84.1 \%$ think that their computer knowledge is very good or excellent.

Table 6. How Much Computer Knowledge Students Have

\begin{tabular}{ccccccc} 
Answer & $\begin{array}{c}\text { 1-bad computer } \\
\text { knowledge }\end{array}$ & $\mathbf{2}$ & $\mathbf{3}$ & $\mathbf{4}$ & $\begin{array}{c}\text { 5-excellent computer } \\
\text { knowledge }\end{array}$ & Total \\
\hline$\%$ of answers & 0,0 & 0,0 & 15,9 & 56,3 & 27,8 & 100,0
\end{tabular}

$\mathrm{M}=4,1 \% ; \mathrm{SD}=0,6 \%$

6. $22.4 \%$ of the students think that the Internet-based learning does not affect their study. $17.6 \%$ of the respondents think that it has an affect on their study, the others would use it to restore a balance between study commitments, work and family. 
Table 7. How Would Internet-Based Learning Affect the Study

\begin{tabular}{cccccc} 
Answer & $\begin{array}{c}\text { Eases } \\
\text { the study }\end{array}$ & $\begin{array}{c}\text { Makes the study } \\
\text { more effective }\end{array}$ & $\begin{array}{c}\text { Restores a balance between } \\
\text { study, work and family }\end{array}$ & $\begin{array}{c}\text { Has no } \\
\text { affect }\end{array}$ & Total \\
\hline \% of answers & 11,7 & 5,9 & 59,6 & 22.8 & 100,0
\end{tabular}

7. Finally students answered the question how useful and appropriate is e-learning for different levels of education and learning styles. They could choose from a range of answers: 5-most appropriate, 1-least appropriate. In the case of postgraduate education more than $46 \%$ of the students have chosen $4(\mathrm{M}=3,9)$ and in the case of non-formal education more than $42 \%$ of the respondents answer $5(\mathrm{M}=4,1)$. For "education by course units" the most frequent answer was 4 , since more than $35 \%$ of the participants have chosen this answer $(M=3,8)$. For graduate study more than $46 \%$ of the students have chosen answer $3(M=2,9)$, and in the case of secondary school education $34 \%$ of respondents think that e-learning is totally inappropriate, while $30.1 \%$ would choose 2 as an answer $(M=2,0)$.

Table 8. Median and Mean Values Regarding the Appropriateness of Introducing E-Learning in Different Levels of Education

\begin{tabular}{cccccc}
$\begin{array}{c}\text { Level / style } \\
\text { of the study }\end{array}$ & Secondary & Graduate & Postgraduate & $\begin{array}{c}\text { Study by } \\
\text { "course units" }\end{array}$ & $\begin{array}{c}\text { Non-formal } \\
\text { education }\end{array}$ \\
\hline Median value $(\mathrm{Me})$ & 1 & 3 & 4 & 4 & 5 \\
Mean value (M) & 2,0 & 2,9 & 3,9 & 3,8 & 4,1
\end{tabular}

\section{CONCLUSIONS}

Based on the results of the research, now we are able to answer the research questions.

1) The answer analysis showed that the respondents mostly recognize knowledge and skills gained through work experience; they seem less likely to recognize knowledge acquired nonformally as part of a chosen higher education study program. They explicitly support the introduction of "education by course units."

2) In analyzing the second question, we can conclude that internet accessibility is high - only $1 \%$ of the respondents do not use the internet, $16.5 \%$ use it only at work, while the others have the possibility to use it at home. $56.3 \%$ of respondents think they know how to use a computer well (on the scale from 1-5 they chose 4 ), while $27.8 \%$ think they are very skillful with computers. Computer equipment and respondents qualifications for using computers are therefore excellent.

3) Most of the respondents (59.6\%) think that the main advantage of e-learning is to restore a balance between study commitments, work and family. Obviously the highest support for elearning seems to be in the field of non formal education, than in postgraduate education, in "education by course units" and the lowest in undergraduate education and before university education. 
Higher education institutions should support lifelong learning and study the possibilities of recognizing knowledge and skills gained through work experience as well as knowledge acquired non-formally as part of the study programs. They should also give more attention to the organization of education and introduce the study by course units; they should accept different ways of learning such as the e-learning, the adoption of which is desired at the level of nonformal education, postgraduate study and study by course units. The existent legislation enables its use, all education participants and, above all, employers demand its use.

Standards for recognizing different forms and ways of lifelong learning and education as part of the study program should be defined. As the standards and criteria will be set by higher education institutions themselves, there will be a tough competition among them; they will have to offer very qualitative programs in order to survive.

There are still many opened issues such as investigating the efficiency of e-learning, its advantages and disadvantages. We might also be interested in some other factors influencing life long learning and e-learning such as demographic factors.

Although the concept of e-learning is relatively new, this tool of lifelong learning is developing so fast that some refer to it as mobile-learning [3]. Undoubtedly, it is one of the most important elements of a successful and efficient higher education system in the $21^{\text {st }}$ century. In Canada, $57 \%$ of all secondary schools and universities offer on-line programs, while in the academic year 1997/98 these were offered by $44 \%$ of all higher education institutions in America. $85 \%$ of all institutions have introduced distance learning. The importance of e-learning is growing also in Slovenia. In the future we can expect an even faster development due to an adapted legislation [5].

\section{REFERENCES}

1. Brookshire, R. G. (2003). Letter from the editor: Lifelong learning: Practice what you preach: Information Technology, Learning and Performance Journal, $21,2$.

2. Burns, S. (2005). E-Learning: The future of quality training: Quality Progress, 38, 2.

3. Davies, J., and N. Pigott. (2004). E-learning across the Atlantic: Perspectives, 8, 2.

4. European Unit EURYDICE. (2000). Vseživljenjsko učenje: prispevek izobraževalnih sistemov v državah članicah Evropske unije. Rezultati študije. Ljubljana: EURYDICE, 7-12.

5. Higher education act: Official Journal, 100, 13.9.2004, 12010.

6. Lesjak, D., V. Sulčič, N. T. Širca., \& V. Vehovar. (2004). Information and communication technology in tertiary education institutions in Slovenia: A prerequisite for e-learning: Issues in Information Systems, 5(1), 187-93.

7. Moisio, A, and R. Smeds. (2004). E-learning: A service offering: Knowledge and Process Management, i, 4.

8. Munro, A. R., \& J. E. Rice Munro. (2004). Learning styles, teaching approaches, and technology: The Journal of Quality and Participation, 27, 1.

9. Thornbory, G. (2003). E-learning: The revolution: Occupational Health, 55, 2.

10. Trunk, Š. N., \& V. Sulčič. (2005). Lifelong learning: Case study in higher education in Slovenia: International Journal of Innovation and Learning, 2, 142-51. 